\title{
Presynaptic calcium stores underlie large-amplitude miniature IPSCs and spontaneous calcium transients
}

\author{
I. Llano ${ }^{1}$, J. González ${ }^{1}$, C. Caputo ${ }^{2}$, F. A. Lai ${ }^{3}$, L. M. Blayney ${ }^{3}$, Y. P. Tan ${ }^{4}$ and A. Marty ${ }^{1}$ \\ ${ }^{1}$ Arbeitsgruppe Zelluläre Neurobiologie, Max-Planck-Institut für biophysikalische Chemie, 37077 Göttingen, Germany \\ 2 Centro de Biofisica, IVIC, Apartado 21827, Caracas 1020A, Venezuela \\ 3 University of Wales, Division of Medicine-Cardiology, WHRI Building, Heath Park, Cardiff CF44XN, UK \\ ${ }^{4}$ Bogazici Universitei, BMME PK2, Bebek, Istanbul, Turkey \\ Correspondence should be addressed to I.L. (illano@gwdg.de)
}

\begin{abstract}
The cellular mechanisms responsible for large miniature currents in some brain synapses remain undefined. In Purkinje cells, we found that large-amplitude miniature inhibitory postsynaptic currents (mIPSCs) were inhibited by ryanodine or by long-term removal of extracellular $\mathrm{Ca}^{2+}$. Twophoton $\mathrm{Ca}^{2+}$ imaging revealed random, ryanodine-sensitive intracellular $\mathrm{Ca}^{2+}$ transients, spatially constrained at putative presynaptic terminals. At high concentration, ryanodine decreased actionpotential-evoked rises in intracellular $\mathrm{Ca}^{2+}$. Immuno-localization showed ryanodine receptors in these terminals. Our data suggest that large mIPSCs are multivesicular events regulated by $\mathrm{Ca}^{2+}$ release from ryanodine-sensitive presynaptic $\mathrm{Ca}^{2+}$ stores.
\end{abstract}

The building block of synaptic transmission is the quantum, the minimal increment of postsynaptic signals ${ }^{1}$. At vertebrate neuromuscular junctions, the quantum may be equated with spontaneous signals obtained in the absence of presynaptic action potentials, called miniature currents (or potentials) and believed to be due to release of one neurotransmitter vesicle. For central synapses, this issue remains an open question, as large miniature currents are suggested to arise from the concerted release of several presynaptic vesicles and to be the sum of several quanta ${ }^{2-5}$. Such multivesicular miniature events could reflect tetrodotoxinresistant action potentials in presynaptic terminals ${ }^{6}$. Another explanation comes from evidence for functional intracellular $\mathrm{Ca}^{2+}$ stores in presynaptic terminals. First, inositoltrisphosphate $\left(\mathrm{InsP}_{3}\right)$ receptors are immunolocalized in presynaptic terminals of the deep cerebellar nuclei and retina ${ }^{7,8}$. Second, at the frog neuromuscular junction, agents that affect ryanodine-sensitive $\mathrm{Ca}^{2+}$ stores also regulate presynaptic intracellular $\mathrm{Ca}^{2+}\left(\mathrm{Ca}^{2+}{ }_{\mathrm{i}}\right)$ rises and acetylcholine release during high-frequency stimulation $^{9,10}$. Third, action-potential-evoked release of acetylcholine at synapses in Aplysia buccal ganglia is inhibited by ryanodine and augmented by presynaptic injection of cyclic ADP ribose ${ }^{11}$. Fourth, caffeine and/or ryanodine modify presynaptic $\mathrm{Ca}^{2+}{ }_{\mathrm{i}}$ signals in autonomic ganglia ${ }^{12,13}$ and in photoreceptors ${ }^{14}$. Finally, in hippocampal pyramidal cells, caffeine or thapsigargin can increase the frequency of miniature IPSCs ${ }^{15}$. Hence, spontaneous $\mathrm{Ca}^{2+}$ release from presynaptic $\mathrm{Ca}^{2+}$ stores may provide the synchronization mechanism that leads to multivesicular miniatures. However, except for one study that gave negative results in cultured retinal amacrine cells ${ }^{16}$, this possibility has not been tested systematically.

To assess the contribution of intracellular $\mathrm{Ca}^{2+}$ stores to neurotransmitter release, we monitored the amplitude distribution of miniature synaptic currents while manipulating potential presy- naptic $\mathrm{Ca}^{2+}$ stores. Using cerebellar interneuron-Purkinje cell synapses, in which large miniature synaptic currents are prominent, we found that the largest mIPSCs result from multivesicular release and depend on $\mathrm{Ca}^{2+}$ mobilization from ryanodine-sensitive presynaptic stores. Further, two-photon confocal microscopy showed ryanodine-sensitive intracellular $\mathrm{Ca}^{2+}{ }_{\mathrm{i}}$ transients highly localized to presumed release sites, which may underlie large miniature currents.

\section{RESULTS}

Miniature IPSCs recorded in cerebellar Purkinje cells, at $-60 \mathrm{mV}$ under symmetrical $\mathrm{Cl}^{-}$concentrations and in the presence of tetrodotoxin (TTX) and ionotropic glutamate receptor blockers, showed mean amplitudes of $125 \pm 9 \mathrm{pA}(n=28$ cells), larger than for most neurons (Fig. 1a). Amplitude histograms had a distinct peak for values less than $200 \mathrm{pA}$, followed by a long tail with amplitudes up to $1500 \mathrm{pA}$ (Fig. 1b). Spurious summation of independent events did not contribute to the generation of largeamplitude mIPSCS. In the example shown, an upper estimate of random double events based on mIPSC frequency $(4.3 \mathrm{~Hz})$ and effective discrimination time among events $(3 \mathrm{~ms})$ was 10 , whereas the observed number of events greater than 200 pA was 346, showing that $\leq 3 \%$ of these large events are due to random summation of single mIPSCs. Here we investigate the mechanisms underlying large-amplitude mIPSCs (lamIPSCs), with amplitudes from 200 to $1500 \mathrm{pA}$.

\section{Effects of external calcium concentration}

Because of their large size, we proposed that lamIPSCs resulted from synchronized release of several neurotransmitter-filled vesicles triggered by voltage-dependent $\mathrm{Ca}^{2+}$ entry or intracellular $\mathrm{Ca}^{2+}$ release from presynaptic stores. To discriminate between these possibilities, we examined the effects on the frequency and 
Fig. 1. Large-amplitude mIPSC $s$ in cerebellar Purkinje cells are sensitive to extracellular $\mathrm{Ca}^{2+}$ concentration. (a, b) Large-amplitude mIPSC $s$ recorded in a Purkinje cell from a 12-day-old rat. (a) $\mathrm{N}$ ine consecutive mIPSC $\mathrm{s}$ after alignment of the rising phases. (b) First component up to $200 \mathrm{pA}$ and prominent tail extending to 1600 pA (771 events, from a 3-min recording period; mean mIPSC amplitude and frequency are $283 \mathrm{pA}$ and $4.3 \mathrm{~Hz}$ ). (c, d) Effects of reducing extracellular $\mathrm{Ca}^{2+}$ concentration $\left(\mathrm{Ca}^{2+}{ }_{0}\right)$ from the normal $2 \mathrm{mM}$ to $0.1 \mathrm{mM}$ (same cell as in $\mathbf{a}$ and $\mathbf{b})$. Frequency and amplitude of mIPSC s decrease slowly during the time in $0.1 \mathrm{mM} \mathrm{Ca}{ }^{2+}$. Rapid fall of mean frequency, but not mean amplitude, immediately following solution change. (e, f) Upon increasing $\mathrm{Ca}^{2+}{ }_{0}$ to $5 \mathrm{mM}$, mIPSC frequency quickly and reversibly increased; mIPSC amplitude was not significantly modified (from a different cell). $(\mathbf{g} \mathbf{~ h})$ Average results from seven experiments such as in (a-f). Averages calculated over last three min in test solution. Significant differences to control results in $2 \mathrm{mM} \mathrm{Ca}{ }^{2+}{ }_{0}$ ${ }^{*} p<0.05 ; *{ }^{* *}<0.001$, paired t-test.
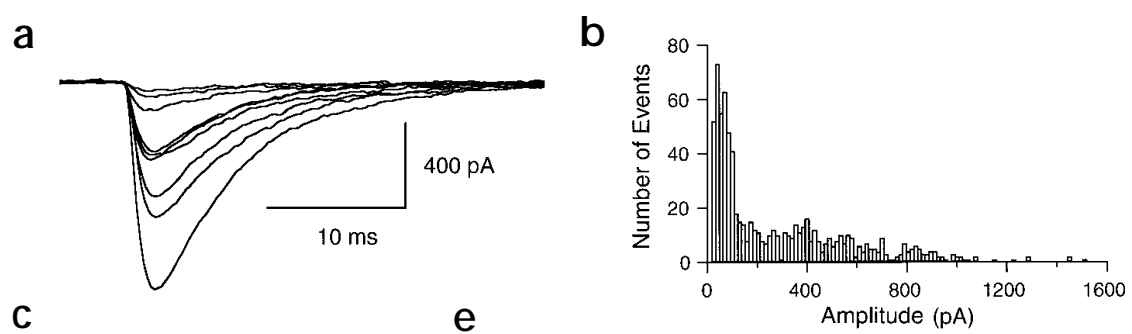

\section{d}
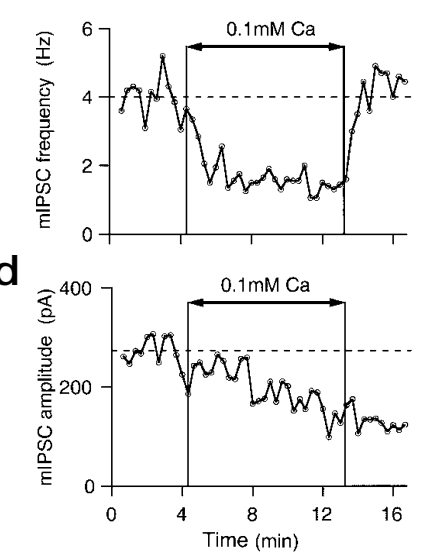

e
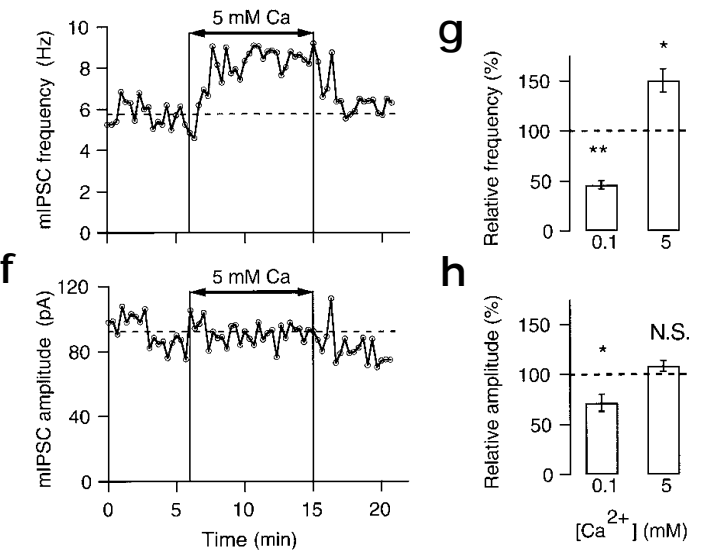

mean distribution of mIPSCs when we changed the extracellular $\mathrm{Ca}^{2+}$ concentration $\left(\mathrm{Ca}^{2+}{ }_{\mathrm{o}}\right)$.

When $\mathrm{Ca}^{2+}{ }_{0}$ was reduced to $0.1 \mathrm{mM}$, mIPSC frequency fell abruptly to about half the control value, slowly declined during continued exposure to low $\mathrm{Ca}^{2+}{ }_{0}$, and then readily recovered its initial value upon washing (Fig. 1c). However, the mean amplitude of mIPSCs did not immediately change, but steadily declined during low $\mathrm{Ca}^{2+}{ }_{0}$, with no recovery upon washing (Fig. 1d). Pooled results indicated that lowering $\mathrm{Ca}^{2+}{ }_{o}$ produced significant reductions of mIPSC frequency and amplitude (Fig. $1 \mathrm{~g}$ and $\mathrm{h}$ ).

With $\mathrm{Ca}^{2+}{ }_{\mathrm{o}}$ above its resting value, the frequency of mIPSCs increased rapidly and reversibly (Fig. 1e). No amplitude change occurred in the example shown (Fig. 1f), but others showed a

a

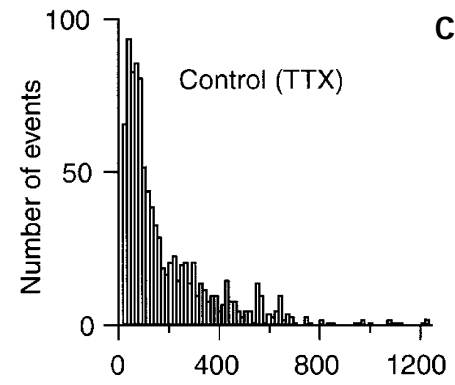

b

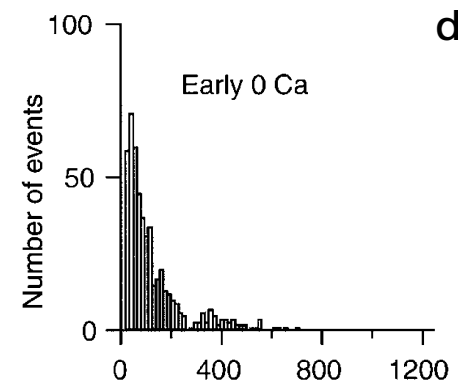

C
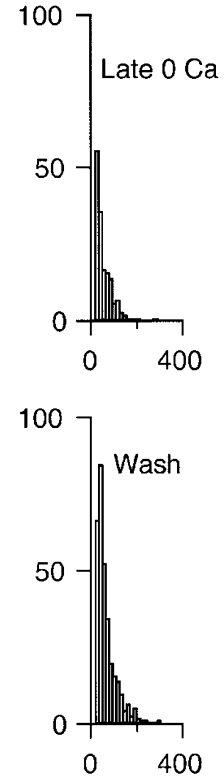

small increase. Pooled results showed a strong and significant frequency increase, and a statistically insignificant amplitude increase (Fig. $1 \mathrm{~g}$ and $\mathrm{h}$ ). Thus, $\mathrm{Ca}^{2+}{ }_{\mathrm{o}}$ strongly influences mIPSCs in Purkinje cells, although frequency and amplitude are differentially modulated. The rapid change in frequency (Fig. 1c) indicated that cytosolic $\mathrm{Ca}^{2+}$ reacted quickly to changes in $\mathrm{Ca}^{2+}{ }_{0}$, whereas the slow amplitude change suggested an influence of extracellular $\mathrm{Ca}^{2+}$ on presynaptic stores ${ }^{17}$.

The slow decrease in mean mIPSC amplitude in low $\mathrm{Ca}^{2+}{ }_{\mathrm{o}}$ (Fig. 1d) suggested that prolonged extracellular $\mathrm{Ca}^{2+}$ removal could cause selective elimination of lamIPSCs. To test this possibility, we followed mIPSC amplitude distributions during total and prolonged removal of extracellular $\mathrm{Ca}^{2+}$. Shortly after application of a $\mathrm{Ca}^{2+}$-free, EGTA-containing extracellular solution, many lamIPSCs ( $\geq 200$ pA) were still observed (compare Fig. 2a and b). Later, however, amplitudes became much more homogeneous compared to control, and the proportion of lamIPSCs was reduced (Fig. 2c

Fig. 2. Changes in mIPSC amplitude distributions after prolonged periods in $\mathrm{Ca}^{2+}$-free external solution. (a-d) Amplitude histograms in $2 \mathrm{mM} \mathrm{Ca}^{2+}{ }_{0}(\mathbf{a}), 0-6 \mathrm{~min}(\mathbf{b})$ and 15-21 min (c) after switching to a $\mathrm{Ca}^{2+}$-free external solution containing $0.2 \mathrm{mM}$ EGTA, $\geq 3$ min after washing back to the original solution (d). All solutions contained TTX. $H$ istograms represent 6 min of data, and correspond to event frequencies of $2.7 \mathrm{~Hz}(\mathbf{a}), 1.4 \mathrm{~Hz}$ (b), $0.4 \mathrm{~Hz}$ (c) and $0.9 \mathrm{~Hz}$ (d). (e) Superimposed cumulative amplitude histograms corresponding to (a-d).

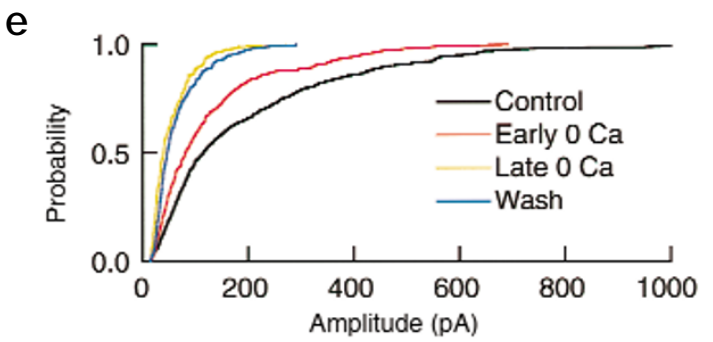


Fig. 3. Time dependence of amplitude and frequency changes during prolonged external $\mathrm{Ca}^{2+}$ removal. (a, b) Time course of mean amplitude and frequency changes, from the experiment of Fig. 2. (c) Average time course of 8 experiments as in (b) (filled circles), using slices originating from animals 10-13 days old, and of 6 sham experiments where the cells were maintained in the $\mathrm{Ca}^{2+}$. containing external solution throughout (open circles, matched age group). (d, e) Paired Student's t-tests indicate significant changes in mean amplitude and frequency between mIPSC s recorded during a 3-min control period and after 15-18 min in $\mathrm{Ca}^{2+}$ - free external solution ( $\mathbf{d}$, left, mean values in control and in $\mathrm{Ca}^{2+}$-free solution, $4.2 \pm 0.7 \mathrm{~Hz}$ and $0.6 \pm 0.1 \mathrm{~Hz}, * \mathrm{p}<0.01$ $n=8)$, and no significant change for the sham experiments in $2 \mathrm{mM} \mathrm{Ca}{ }^{2+}$ (right, $\mathrm{n}=6$ ). Error bars in (c-e), s.e.m. (f) Time course of decay of mIPSC amplitudes in $\mathrm{Ca}^{2+}$-free external solution (filled circles; mean timeplot results, normalized to an initial amplitude of 1 and to an amplitude of 0 at $21 \mathrm{~min}$ ) is much slower than that of depolarizationinduced $\mathrm{C}^{2+}{ }_{i}$ transients at a presumed presynaptic terminal (triangles). The latter set of points correspond to the $\mathrm{Ca}^{2+}{ }_{i}$ rises evoked by $50 \mathrm{~ms}$ depolarization to $0 \mathrm{mV}$, recorded using two-photon scanning microscopy in a basket cell axon dialyzed with a solution con-

taining $200 \mu \mathrm{M} 0$ regon G reen-1 and $140 \mathrm{mM} \mathrm{Cs}{ }^{+}$as the main cation. (Peak $\Delta \mathrm{F} / \mathrm{Fo}$ values have been normalized to the average of points for the control period.) Data points for mIPSC amplitudes have been displaced along the time axis so that the time of extracellular $\mathrm{Ca}^{2+}$ removal is identical for the two data sets. Solid horizontal bar, period of $\mathrm{Ca}^{2+}{ }_{0}$ removal for the mIPSC data; dashed bar, $\mathrm{Ca}^{2+}{ }_{0}$ removal for the $\mathrm{Ca}^{2+}{ }_{i}$ data.

and e), on average from $22.7 \pm 3.5 \%$ in control to $4.4 \pm 2.0 \%$ after $15-18$ minutes in $\mathrm{Ca}^{2+}$-free external solution $(p<0.001, n=8)$.

As in the $0.1 \mathrm{mM} \mathrm{Ca}^{2+}{ }_{\mathrm{o}}$ experiments, the effect of total external $\mathrm{Ca}^{2+}$ removal on frequency was biphasic; a fast initial drop was followed by a slower decrease (Fig. 3a), and the effects on amplitude were slow (Fig. 3 b and c, filled symbols). Upon return to the $\mathrm{Ca}^{2+}$-containing solution, there was a modest recovery of mIPSC frequency and amplitude (Fig. $3 \mathbf{a}$ and $\mathbf{b}$ ). After 15-18 minutes in $\mathrm{Ca}^{2+}$-free external solution, mean mIPSC frequency was 7-fold lower than in control (Fig. 3d, left). The mean amplitude decreased to $57 \mathrm{pA}$, a value 2.4 -fold smaller than the control ( $p<0.01, n=8$; Fig. 3e, left).

To determine possible mIPSC rundown ${ }^{18}$, we followed cells over the same time course as in the $\mathrm{Ca}^{2+}$-free experiments without changing the external solution ('sham experiments'). No significant change occurred in the mIPSC amplitude (Fig. $3 \mathrm{c}$ and e, right) or frequency (Fig. 3d, right), showing that mIPSC rundown cannot account for the changes in Fig. 2.

Elevations in the $\mathrm{Ca}^{2+}{ }_{\mathrm{i}}$ concentration of Purkinje cells lead to a short-lived frequency decrease and a long-lasting amplitude increase of mIPSCs ${ }^{19,20}$. However, because $\mathrm{Ca}^{2+}{ }_{\mathrm{i}}$ in the recorded cell was buffered with 10 mM BAPTA, manipulations of $\mathrm{Ca}^{2+}{ }_{0}$ are unlikely to have affected mIPSCs by this pathway. Indeed, responses to exogenous applications of the $\mathrm{GABA}_{\mathrm{A}}$ agonist muscimol were unchanged after 15-18 minutes in $\mathrm{Ca}^{2+}$-free external solution (mean ratio of the currents in the $\mathrm{Ca}^{2+}$-free solution to control value, $1.15 \pm 0.22 ; n=5)$. Thus, the strong reduction in mIPSC amplitude observed after external $\mathrm{Ca}^{2+}$ removal is not due to postsynaptic modifications.

\section{TTX-insensitive $\mathbf{C a}^{2+}$ spikes do not cause lamIPSCs}

A presynaptic mechanism that could explain lamIPSCs would be multivesicular release driven by TTX-insensitive axonal $\mathrm{Ca}^{2+}$ spikes. Although this hypothesis seems unlikely because of the slow kinetics of frequency and amplitude changes (Fig. 3a-c), diffusion barriers could have delayed extracellular $\mathrm{Ca}^{2+}$ removal at release sites. We followed the presynaptic $\mathrm{Ca}^{2+}{ }_{\mathrm{i}}$ rise (Figs. 6 and 8 below) as a function of time after extracellular $\mathrm{Ca}^{2+}$ removal (Fig. 3f, triangles). After 3-minute exposure to $\mathrm{Ca}^{2+}$ free, EGTA-containing external solution, the $\mathrm{Ca}^{2+}{ }_{\mathrm{i}}$ rises elicited by $50 \mathrm{~ms}$ depolarizations to $0 \mathrm{mV}$ in $\mathrm{Cs}^{+}$-loaded basket cells fell to $6.7 \pm 4.2 \%$ of control ( $n=6$ presynaptic sites from 5 experiments), and after 5 minutes no signal was left in any experiment. After restoration of external $\mathrm{Ca}^{2+}$, presynaptic $\mathrm{Ca}^{2+}{ }_{\mathrm{i}}$ rises returned to normal within a few minutes. This time course contrasts with the slow changes in lamIPSC amplitude upon prolonged removal of $\mathrm{Ca}^{2+}{ }_{0}$ (Fig. 3f). We therefore conclude that the latter does not reflect delayed external $\mathrm{Ca}^{2+}$ removal at the presynaptic release sites. Furthermore, because lamIPSCs were still observed after complete elimination of $\mathrm{Ca}^{2+}$ influx, they are not due to local $\mathrm{Ca}^{2+}$ influx following TTX-insensitive axonal depolarization.

To independently check for the possible participation of axonal voltage-dependent $\mathrm{Ca}^{2+}$ channels in generating lamIPSCs, we used extracellular $\mathrm{Cd}^{2+}$, a nonselective $\mathrm{Ca}^{2+}$ channel blocker, and $\omega$-Aga-IVA, which preferentially inhibits $\mathrm{P} / \mathrm{Q} \mathrm{Ca}^{2+}$ channels. These agents strongly reduce the action-potential-evoked presynaptic $\mathrm{Ca}^{2+}{ }_{\mathrm{i}}$ transients recorded in axons and presumed presynaptic terminals of cerebellar interneurons ${ }^{21}$. We found that $\mathrm{Cd}^{2+}$ 
Fig. 4. Rise time of mIPSC $s$ in control conditions and after external $\mathrm{Ca}^{2+}$ removal. $(\mathbf{a}, \mathbf{b})$ Example rising phases of mIPSC $s$ in control conditions (a) and after prolonged extracellular $\mathrm{Ca}^{2+}$ removal (b). Time shifts between traces are arbitrary. Note that most traces in (a) have fast rises, whereas most traces in (b) have slow kinetics. (c, d) Amplitudes as a function of $10-90 \%$ rise times, from 3-min periods in control conditions (c) and after prolonged extracellular $\mathrm{Ca}^{2+}$ removal (d). Two populations of mIPSC $s$ can be distinguished in the control, one with fast rise time and (on average) large amplitudes, the other with larger rise times and smaller amplitudes. Following prolonged extracellular $\mathrm{Ca}^{2+}$ removal, the first component is almost abolished, whereas the number of events in the second component is reduced to about $40 \%$ of its initial value. Same cell as in $(\mathbf{a}, \mathbf{b})$. (e, f) Corresponding rise-time histograms. Each histogram was fitted with the sum of two Gaussians. The first peak is centered at $0.7 \mathrm{~ms}$ and accounts for $39 \%$ of the events in the control (e) and $9 \%$ after extracellular $\mathrm{Ca}^{2+}$ removal (f). It contained $61 \%$ of the events larger than $200 \mathrm{pA}$ in the control and $28 \%$ after extracellular $\mathrm{Ca}^{2+}$ removal. The second peak is centered at $2.4 \mathrm{~ms}$ in the control (e) and at 1.8 ms after extracellular $\mathrm{Ca}^{2+}$ removal (f).

and $\omega$-Aga-IVA potently inhibited evoked IPSCs at interneuron-Purkinje cell synapses (after 6-9 min, to $8 \pm 3 \%$ of control in $10 \mu \mathrm{M} \mathrm{Cd}^{2+}, n=3$; to $13 \pm 3 \%$ of control in $200 \mathrm{nM} \omega$-Aga-IVA, $n=4)$, without affecting mIPSC amplitude. Mean amplitudes were $119 \pm 21 \mathrm{pA}(n=3)$ in $10 \mu \mathrm{M} \mathrm{Cd}^{2+}$ and $138 \pm 10 \mathrm{pA}(n=6)$ in $200 \mathrm{nM} \omega$-Aga-IVA, compared to $138 \pm 17 \mathrm{pA}$ in control (Fig. 3e). The percentage of lamIPSCs was also unaltered (after 6-9 min, $\mathrm{Cd}^{2+}, 20.8 \pm 2.2 \%, n=3$; toxin, $21.4 \pm 8.7 \%$; control, $22.7 \pm 3.5 \%$ ) Thus, lamIPSCs are not affected under conditions where depolarization-driven exocytosis is blocked.

In summary, the above evidence indicates that the slow modifications in mIPSC amplitude distribution are not linked to rundown, to altered postsynaptic receptors or to delayed extracellular $\mathrm{Ca}^{2+}$ removal. This leaves multivesicular release under the control of presynaptic $\mathrm{Ca}^{2+}$ stores as the most likely explanation for
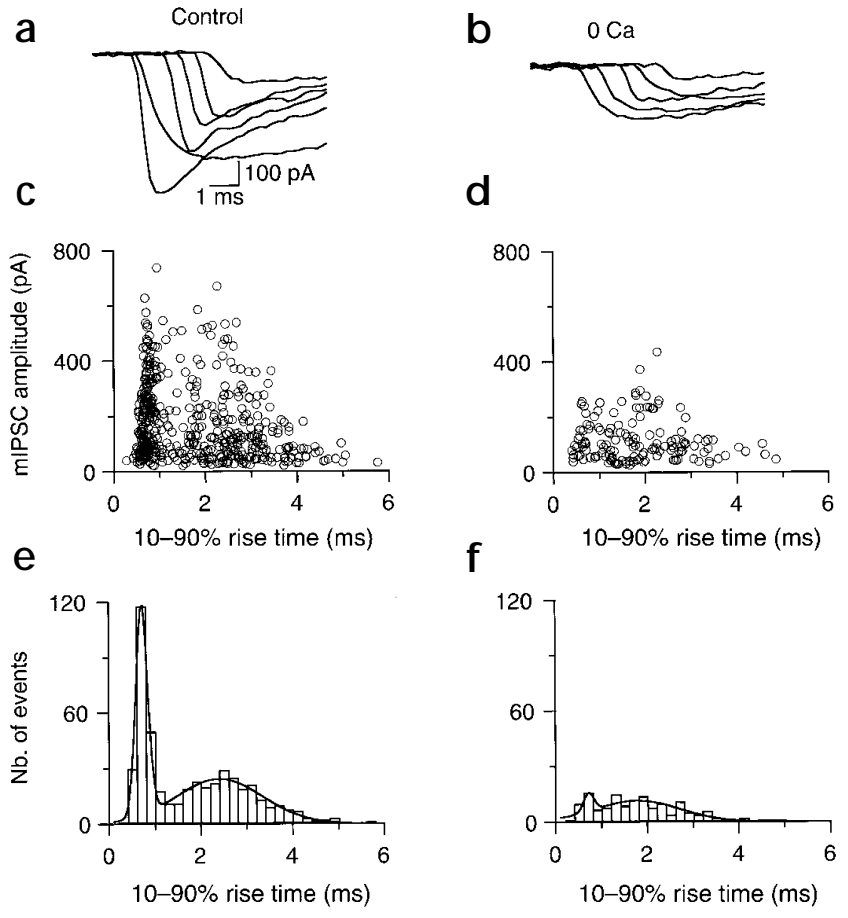

lamIPSCs. The mIPSC amplitude changes would then reflect slow re-equilibration of $\mathrm{Ca}^{2+}$ within presynaptic terminals, leading to gradual depletion of presynaptic $\mathrm{Ca}^{2+}$ stores. To explain the lack of recovery of mIPSC amplitude upon $\mathrm{Ca}^{2+}{ }_{\mathrm{o}}$ restoration, we have to assume that store refilling is inefficient in our experimental conditions, where action potentials and subsequent $\mathrm{Ca}^{2+}$ influx are blocked.

\section{Rise time kinetics}

The proposed multivesicular release seems difficult to reconcile with the smooth rising phases of many mIPSCs, including

Fig. 5. Immunohistochemical evidence that basket cell terminals contain RyRs. (a, b) Immunoblot analysis with anti-RyR antibody. (a) Consensus antiRyR antibody (unpurified) was used to probe immunoblots of skeletal muscle, cardiac muscle and whole-brain microsomal membrane proteins (lane $S$, $C, B r$, respectively) following electrophoresis on a $5 \%$ SD S gel. N umbered arrowheads indicate the position of molecular weight markers in $\mathrm{kD}$. (b) Affinity-purified RyR antibody was used for immunoblot analysis of skeletal muscle, cardiac muscle and cerebellum microsomal membrane proteins (lane $S, C, C$, respectively) following electrophoresis on a $5 \%$ SD S gel. The RyR antibody was affinity-purified (Methods) with either muscle RyR protein (top) or Protein A (middle), or preincubated with native RyR protein from muscle microsomes after affinity purification with Protein A (bottom). (c, d) Immunostaining of rat cerebellar slices. (c) Low-power magnification, showing marked staining of axons and presynaptic structures in the Purkinje cell layer and in the proximal molecular layer. Purkinje cell somata and dendrites are also stained, albeit more weakly. Scattered highly stained structures in the granule cell layer include Purkinje cell axons and presumed glomeruli. (d) Photomontage from three confocal image planes spaced $2 \mu \mathrm{m}$ apart, at higher magnification. Basket cell terminals onto somata of three Purkinje cells (P1, P2, P3) and of a basket cell (Bs) are prominently stained. The section shown is almost tangential to P2. In the molecular layer, basket cell axons ( $\mathrm{Ba}$ ) are stained. These axons run parallel to the Purkinje cell layer, in the immediate vicinity of Purkinje cell somata, and could be followed over distances up to $200 \mu \mathrm{m}$. $\mathrm{N}$ umerous stained dot-like structures in the molecular layer, including two that are in close apposition to the main dendrite of $\mathrm{P} 1$, which probably represent en passant endings from basket or stellate cell axons.

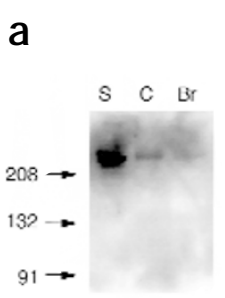

C

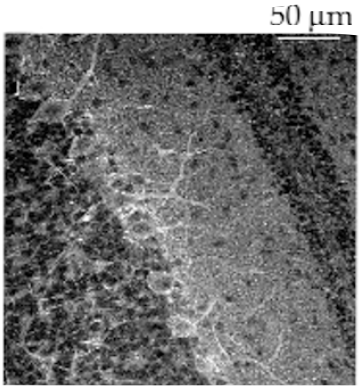

b

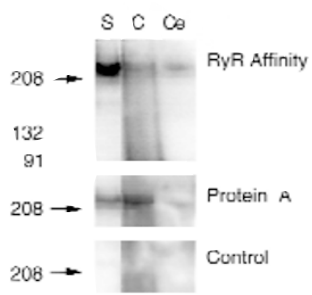

d

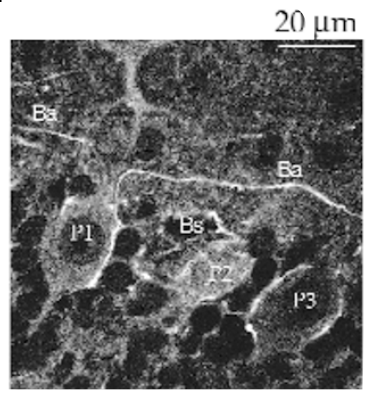


Fig. 6. Ryanodine inhibits $\mathrm{Ca}^{2+}{ }_{i}$ rises induced by action potentials at basket cell terminals. (a, b) Two-photon scanning microscope images from presumed basket cell terminals in the close vicinity of a Purkinje cell soma. The presynaptic cell was loaded with a $\mathrm{KCl}$ solution containing $200 \mu \mathrm{M}$ of 0 regon $\mathrm{G}$ reen 1. Images ( $67 \mathrm{~ms}$ exposure) are shown at rest (a) and near the peak of the response to a train of 4 action potentials (b). (c, d) Relative fluorescence changes recorded in three regions of interest (ROIs, as depicted in $\mathbf{b}$ ) in responses to trains of 4 action potentials (arrows) Each trace is the average of 10 responses recorded at approximately 1-min intervals in control (c) and during the 5-15 min following addition of $100 \mu \mathrm{M}$ ryanodine (d). O n average, the peak $\mathrm{Ca}^{2+}{ }_{i}$ response was reduced to $0.77 \pm 0.08$ of the control $(n=5 ; p<0.05$; data corrected for rundown by linear extrapolation), $59 \%$ of the control values, after $11-15$ min of exposure to $100 \mu \mathrm{M}$ ryanodine. (e) Time course of the changes of the peak fluorescence signals. RO Is 1 and 2 showed transient increases upon application of ryanodine. The plot starts $10 \mathrm{~min}$ after the beginning of whole-cell recording. (f) Ryanodine does not modify the membrane currents recorded in the soma during the stimulation trains.

the largest ones (Fig. 1a). To explain the smooth rises, processes downstream of vesicle mobilization (for example, GABA release, channel activation or signal filtering associated with passive cell properties or recording pipette resistance) would need to be rate limiting. Thus, we studied the rise time of mIPSCs as a function of amplitude after extended external $\mathrm{Ca}^{2+}$ removal (Fig. 4).

In 6 of 8 control cells, mIPSC rise time kinetics were heterogeneous (Fig. 4a), with two populations (Fig. $4 \mathrm{c}$ and e). One subpopulation had rise times centered around $1 \mathrm{~ms}(0.7 \mathrm{~ms}$ in Fig. 4c) and large amplitudes (mean, 208 pA in Fig. 4c), and the second had rise times ranging from 2 to $5 \mathrm{~ms}$, smaller amplitudes (mean, 151 pA in Fig. 4d) and slower decay kinetics (data not shown). The two remaining cells showed a single broad component in the amplitude-rise time plot.

In juvenile Purkinje cells (10-13 days), somatic synaptic currents are faithfully recorded, and distal dendritic inputs are slowed down by an effective first-order filter with a characteristic time constant near $1 \mathrm{~ms}$ (range $0.7-1.3 \mathrm{~ms}$, determined according to ref. 22). Because of the additional delay associated with the activation of $\mathrm{GABA}_{\mathrm{A}}$ channels (about $\left.1 \mathrm{~ms}\right)^{23}$, dendritic monovesicular events are expected to have $10-90 \%$ rise times of at least $2 \mathrm{~ms}$. Therefore the fast rise time mIPSCs occur at synapses located on the soma or proximal dendrites.

During external $\mathrm{Ca}^{2+}$ removal, the first component of the rise time histogram did not change position, but its relative amplitude gradually declined (example, from $39 \%$ to $9 \%$; Fig. 4 e and f), leaving mostly slow events. Similar results were observed in 5 of 6 cells, where two components were apparent in the control run. In the sixth cell, the fast component was less reduced than the slow one. Thus, fast mIPSCs are more sensitive to external $\mathrm{Ca}^{2+}$ removal than slow ones.

These results suggest that lamIPSCs primarily belong to a class of fast-rising mIPSCs that originate at somatic synapses. If lamIPSCs are multivesicular, the synchronization mechanism must occur in the submillisecond range for these somatic events. A smaller proportion of lamIPSCs has slower rise times and decays, and is less sensitive to external $\mathrm{Ca}^{2+}$ removal. These lamIPSCs could be dendritic, and could have a synchronization mechanism lasting 1-4 ms.

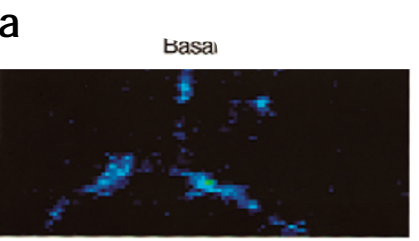

$5 \mu \mathrm{m}$

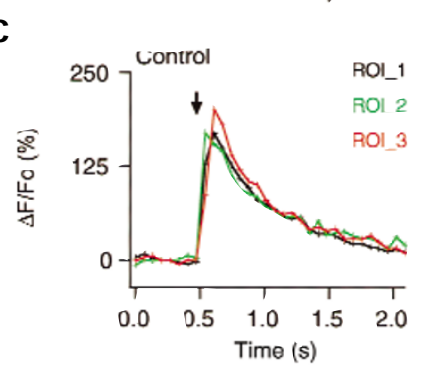

e

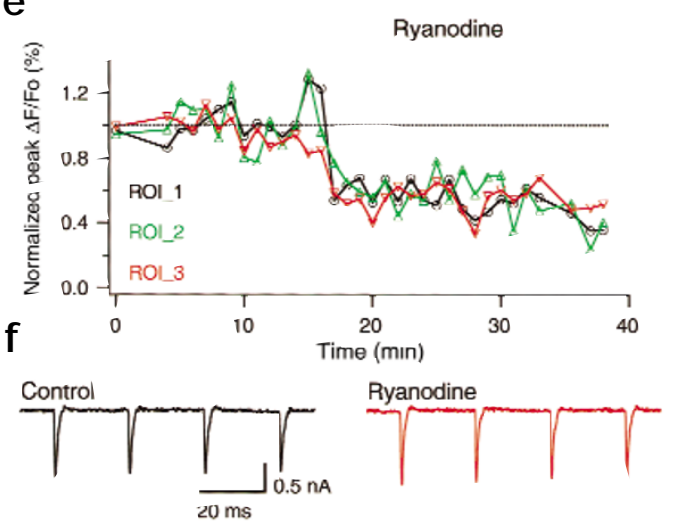

\section{Role of ryanodine receptors}

Ryanodine receptors (RyRs) are widely distributed in the mammalian brain ${ }^{24}$, so we looked for them in synaptic terminals of cerebellar interneurons. Immunohistochemistry shows RyR staining in somata of Purkinje cells and basket cells, but not in terminals of basket cells or any other neuron ${ }^{25,26}$. Postsynaptic staining may have obscured possible staining of adjacent presynaptic terminals, and pre- and postsynaptic RyRs may be of different subtypes and therefore may react with different antibodies. We thus examined rat cerebellar slices with a new consensus antibody that specifically recognizes the mammalian high-molecular-weight RyR isoforms expressed in whole brain, cerebellum and skeletal and cardiac muscle (Fig. 5a and b). At low-power magnification, we saw staining in Purkinje cells (soma and dendrites; Fig. 5c). Additionally, intensely stained fiber-like structures and dots were visible in the Purkinje cell layer, proximal molecular layer and granule cell layer (Fig. 5c). At higher-power magnification, we saw highly stained fibers in the proximal molecular layer running parallel to the Purkinje cell layer, and ending in larger structures surrounding Purkinje cell somata (Fig. 5d). The morphology of these fibers was characteristic of axons and presynaptic terminals of juvenile basket cells ${ }^{27}$. Terminals onto basket cell somata were also strongly labeled (Fig. 5d). Occasionally, we also saw staining of isolated terminals on proximal Purkinje cell dendrites. We observed similar staining patterns in 10 preparations.

These results indicate that a high density of RyRs is present in presynaptic terminals at specific synapses, including basket cell terminals onto Purkinje and basket cell somata. As we 
Fig. 7. Ryanodine-sensitive $\mathrm{C} \mathrm{a}^{2+}$ stores are involved in the generation of lamIPSC s. (a) Superimposed mIPSC amplitude histograms obtained for 3-min periods in control conditions and after 5-8 min exposure to $100 \mu \mathrm{M}$ ryanodine. Ryanodine reduced the mean mIPSC amplitude from $243 \mathrm{pA}$ to $89 \mathrm{pA}$. The mIPSC frequency simultaneously fell from $2.8 \mathrm{~Hz}$ to $0.9 \mathrm{~Hz}$. (b) The corresponding normalized cumulative amplitude histograms show a selective loss of large-amplitude mIPSC $s$ in ryanodine. (c) Time plot of the change of the mean amplitude of mIPSC s, from the same experiment. (d) A verage time plot from a total of 12 experiments. Error bars, s.e.m. (e) The ratio of mean mIPSC amplitude in ryanodine to that in the control solution decreases with the mean mIPSC amplitude measured in control solution. The regression line intersects the value of 1 for an amplitude of $76 \mathrm{pA}$ and falls to 0.52 for the initial maximum mean amplitude value of $250 \mathrm{pA}$. (f) A similar trend is evident when the ratio of mean mIPSC frequency in ryanodine to that in the control solution is plotted as a function of the mean mIPSC amplitude measured in control solution. The regression line intersects the value of 1 for an amplitude of $58 \mathrm{pA}$ and falls to 0.59 for the maximum initial mean amplitude value of $250 \mathrm{pA}$. (g) Responses to applications of muscimol (6-15 $\mu \mathrm{M}$ in puffer pipette) are not modified by ryanodine. Left, superimposed averages from 6 successive applications of $10 \mu \mathrm{M}$ muscimol before and 6-8 min after application of $100 \mu \mathrm{M}$ ryanodine. Right, time plot of the peak current response during ryanodine application.

observed previously, the mean amplitude of mIPSCs recorded in interneurons decreases upon prolonged external $\mathrm{Ca}^{2+}$ removal ${ }^{28}$. (Those changes were smaller than these reported here.) Thus, the staining of terminals onto basket cells is consistent with the possibility that RyRs could be involved in changes of mIPSC amplitude histograms induced by modifications of $\mathrm{Ca}^{2+}{ }_{\text {o }}$

To test whether presynaptic RyRs are functionally involved in interneuron-Purkinje cell synapses, we measured transient rises of presynaptic $\mathrm{Ca}^{2+}{ }_{\mathrm{i}}$ concentration in response to short trains of action potentials. After the entire presynaptic cell is loaded with a high-affinity $\mathrm{Ca}^{2+}$-sensitive dye (Oregon Green BAPTA-1), such responses may be visualized in various subcellular regions, including synaptic terminals onto Purkinje cells ${ }^{29}$. The sensitivity and stability of these measurements are significantly improved by the use of two-photon laser illumination ${ }^{29,30}$. As reported earlier, fluorescence rises were largely restricted to 'hot spots', presumably corresponding to presynaptic terminals and axon branching points ${ }^{29,31}$. In control conditions, peak fluorescence increments measured in hot spots in response to 4-8 action potentials (interval between stimulations, $20 \mathrm{~ms}$ ) averaged $187 \pm 37 \%$ over the resting values (Fig. 6 a-c). Addition of $100 \mu \mathrm{M}$ ryanodine (a saturating concentration) to the bath solution did not significantly alter resting fluorescence level (mean ratio to control, $105 \pm 13 \%, n=4$; at 12-14 minutes after ryanodine application; corrected for slow changes in control data by extrapolation) or somatically recorded currents evoked by stimulation trains (Fig. 6f), but it led to a decrease in action potential-evoked $\mathrm{Ca}^{2+}{ }_{\mathrm{i}}$ transients (Fig. $6 \mathrm{c}$ and d; time course, Fig. 6e). As a test for possible nonspecific effects of ryanodine, we examined the effects of $100 \mu \mathrm{M}$ ryanodine on somatically recorded $\mathrm{Ca}^{2+}$ currents in $\mathrm{Cs}^{+}$-loaded interneurons. We found a mean ratio of $0.97 \pm 0.07$ $(n=5)$ between $\mathrm{Ca}^{2+}$ currents measured 9-12 minutes after addition of ryanodine and control values, indicating that this dose of ryanodine does not modify presynaptic voltage-dependent $\mathrm{Ca}^{2+}$ channels. Overall, we conclude that basket terminals contain functional ryanodine-sensitive $\mathrm{Ca}^{2+}$ stores, which contribute to shaping the $\mathrm{Ca}^{2+}{ }_{\mathrm{i}}$ response to presynaptic action potentials.
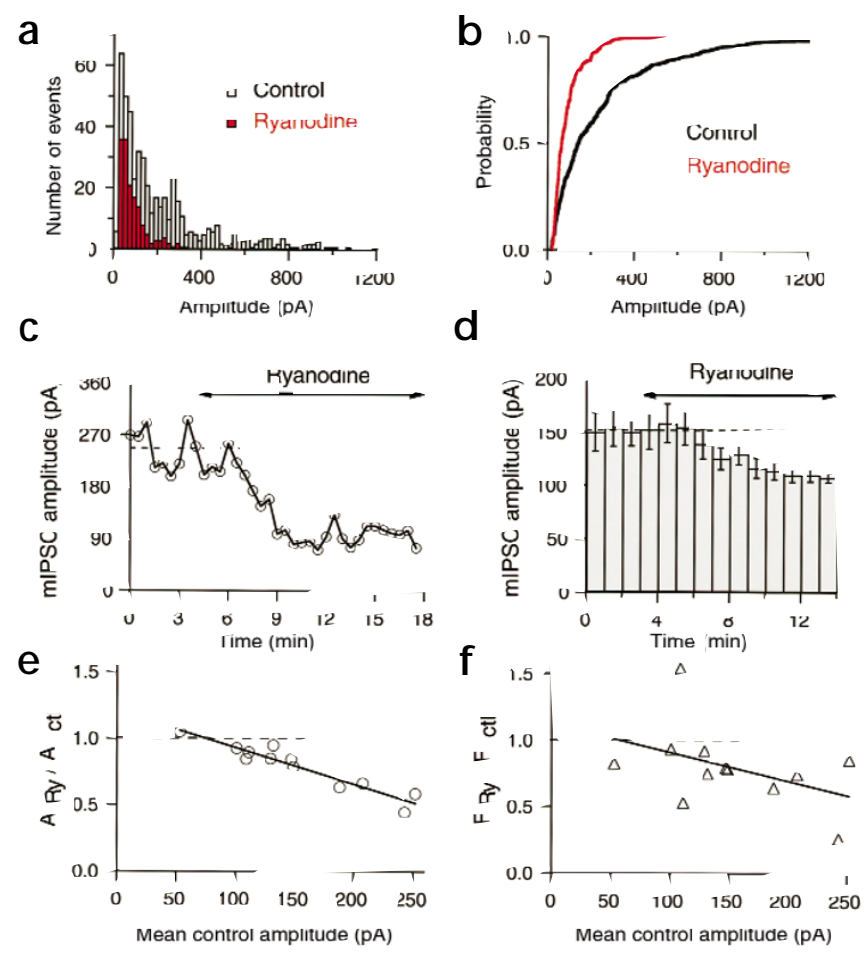

g
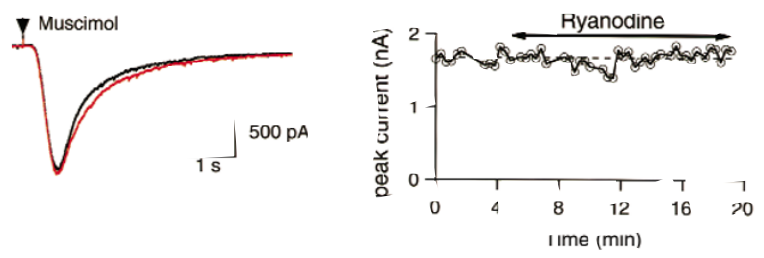

We next tested the effects of high ryanodine concentrations on mIPSCs. In one example, $100 \mu \mathrm{M}$ ryanodine drastically altered the frequency and amplitude profile of mIPSCs (Fig. 7a and $\mathbf{b}$ ). The effect developed with a delay of 5-10 minutes (example, Fig. 7c; summary of 12 experiments, Fig. 7d). On average, this dose of ryanodine significantly reduced mean mIPSC frequency (mean ratio to control, $0.80 \pm 0.09 ; n=12 ; p<0.01$ ) and amplitude (mean ratio, $0.72 \pm 0.07 ; n=12 ; p<0.001$ ). The proportion of events larger than $200 \mathrm{pA}$ dropped from $25.1 \pm 3.6 \%$ to $13.4 \pm 1.5 \%(n=12 ; p<0.01)$ in ryanodine, indicating a selective elimination of lamIPSCs. Frequency and amplitude reductions varied in individual experiments from large (Fig. 7a-c) to small or absent. Control mIPSC amplitude was negatively correlated with amplitude ratio (Fig. $7 \mathrm{e}, p<0.001$ ), and with frequency ratio (Fig. $7 \mathrm{f}, p=0.02$ ), indicating that ryanodine effectiveness depends on the initial percentage of lamIPSCs.

The fits of ryanodine data across experiments intersected ratio values of 1 for mean initial amplitudes near $60 \mathrm{pA}$ (Fig. 7e and f), which corresponds to the value obtained after prolonged deprivation of external $\mathrm{Ca}^{2+}$. These results suggest that monovesicular events have an average amplitude close to $60 \mathrm{pA}$. However, the mean mIPSC amplitude reached in ryanodine was significantly higher than the amplitude reached after prolonged incubation in $\mathrm{Ca}^{2+}$-free external solution. This suggests that ryanodine disrupts the mechanism underlying mIPSC synchronization, but does not abolish it.

We finally tested whether ryanodine could affect the current response to applications of the $\mathrm{GABA}_{\mathrm{A}}$ receptor agonist muscimol 
Fig. 8. Spontaneous $\mathrm{Ca}^{2+}{ }_{i}$ transients in presumed presynaptic terminals. (a) Superimposed bright field and fluorescence two-photon images of the preparation. The Purkinje cell layer is roughly vertical near the center of the picture, and the molecular layer is on the right. The soma of the recorded cell is outside the picture, below its lower border. Its labeled axon makes contacts with somata of several Purkinje cells, including one in the white rectangle representing the area analyzed with two-photon imaging and fluo-4 as $\mathrm{Ca}^{2+}$ indicator. (b) Two-photon scanning microscope image from the rectangular area in (a), including presumed presynaptic terminals (higher fluorescence counts indicating enlargements of the axon). The bath solution contained TTX and elevated $\mathrm{Ca}^{2+}{ }_{0}$ $(6 \mathrm{mM})$. A verage of 100 scans (100 ms each) at rest. The cell was filled with a K-gluconate solution containing $380 \mu \mathrm{M}$ Fluo-4. RO Is 1 and 2 are in direct contact with the soma of the Purkinje cell, whereas RO Is 4- 6 represent probable release sites onto the main dendrite of the same cell. RO I 5 is a 'hot spot' that responded to a short train of action potentials with a highly localized $\mathrm{Ca}^{2+}{ }_{i}$ rise in an earlier part of the experiment, in normal saline $\left(2 \mathrm{mM} \mathrm{Ca}^{2+}{ }_{0}\right.$, no TTX; this first series of recordings was taken with a smaller scanning area that did not include RO Is 1, 2 or 6). (c, d) Time plots of fluo rescence changes during two series of 100 consecutive images (100 ms per image). Each panel depicts the evolution of RO Is 1 through 6 . Note that in (c), the transient is restricted to RO Is 1 and 2, whereas in (d), taken 5 min later, the transient is restricted to RO Is 4-6. (e, f) A nalysis along the lines drawn in (b), during the two transients. Time runs from bottom to top. The left edge of each scan represents the uppermost point of each line. The transient in (f) spreads over about $5 \mu \mathrm{m}$ and that in (e) over about twice this length (assuming that the part outside the imaged area falls off with distance like the part within).

(6-15 $\mu \mathrm{M}$ in puffer pipette; Fig. 7g). The mean current response was $106 \pm 6 \%(n=5)$ of control after 6-9 minutes in ryanodine, indicating that ryanodine had no significant postsynaptic effect.

\section{Spontaneous $\mathrm{Ca}^{2+}{ }_{\mathrm{i}}$ transients in presynaptic terminals}

These results raise the possibility that, in TTX, the spontaneous activation of ryanodine receptors could lead to the release of $\mathrm{Ca}^{2+}$ from intracellular stores in presynaptic terminals. Local $\mathrm{Ca}^{2+}{ }_{\mathrm{i}}$ transients (' $\mathrm{Ca}^{2+}$ sparks') are found in both cardiac and skeletal mus$\mathrm{cle}^{32-34}$, as well as in neurites of PC12 cells and of hippocampal neurons in culture ${ }^{35}$. We searched for similar transients in our preparation. We first identified axonal $\mathrm{Ca}^{2+}$ hot spots, representing presumed presynaptic terminals, by recording responses to short trains of action potentials. An area $(17 \mu \mathrm{m} \times 24 \mu \mathrm{m})$ including the presumed terminals was then repetitively scanned (multiple series of 100 images at $100 \mathrm{~ms}$ per image) in the presence of TTX. To increase the probability of observing $\mathrm{Ca}^{2+}{ }_{\mathrm{i}}$ fluctuations, we raised the $\mathrm{Ca}^{2+}{ }_{0}$ concentration to $6 \mathrm{mM}$, and in most experiments, added moderate concentrations of ryanodine $(5$ or $10 \mu \mathrm{M})$ to the bath solution after a control period.

Spontaneous $\mathrm{Ca}^{2+}{ }_{\mathrm{i}}$ transients (SCTs) were observed at hot spots both before and after addition of ryanodine. SCTs were recorded by two-photon scanning microscopy with fluo-4 as a $\mathrm{Ca}^{2+}$ indicator (Fig. 8). Along an axon in direct apposition to a Purkinje cell soma (Fig. 8a), brighter spots (Fig. 8b, 1, 2, 4, 5, 6) indicate enlargements corresponding to putative synaptic terminals. SCTs were recorded at spots 1-2 (Fig. 8c) and 4-6 (Fig. 8d). Both transients originate at presumed terminals ( 1 and 5 , respectively). Analysis of the spatial profile indicated that one SCT spread over a distance of about $5 \mu \mathrm{m}$ along the axon (Fig. 8f), whereas the other spread over about twice that length (Fig. 8e).

A total of 15 SCTs were found in control periods ( 13 cells; total a

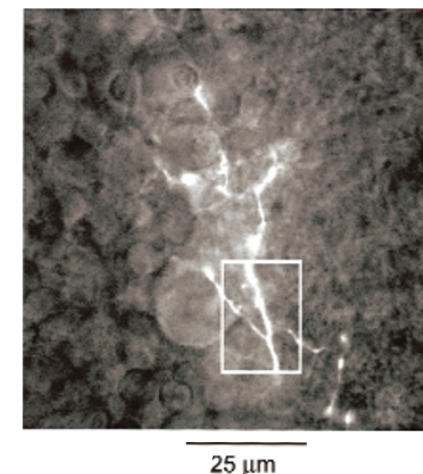

C

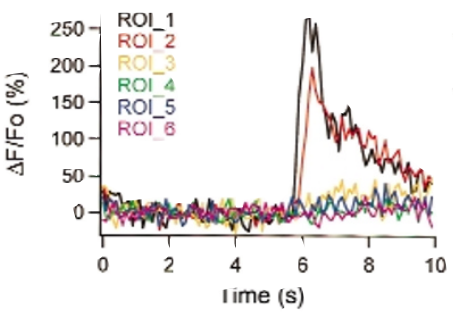

e

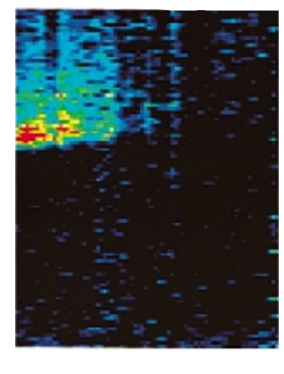

$5 \mu \mathrm{m}$ b

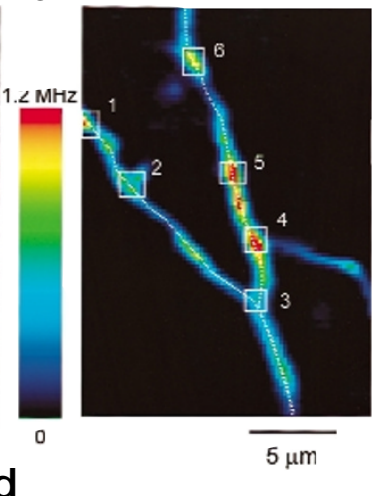

d

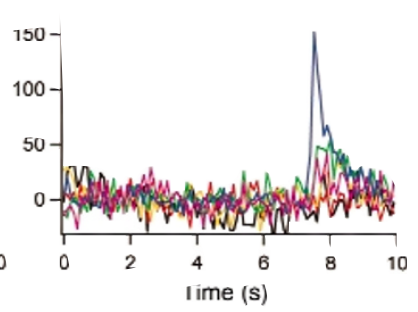

f

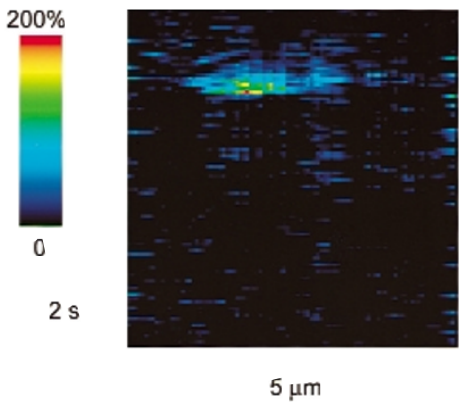

scanning times in individual experiments, 40-270 s), versus 49 in ryanodine (11 cells; analyzed during a window of 2-10 min after ryanodine addition; total scanning times, 70-280 s). The average SCT frequency across cells was significantly lower in control $(0.005 \pm 0.003 \mathrm{~Hz}, n=14)$ than in ryanodine $(0.019 \pm$ $0.007 \mathrm{~Hz}, n=11, p<0.05$ ). (These frequencies were calculated for one $17 \mu \mathrm{m} \times 24 \mu \mathrm{m}$ frame, containing, on average, 5 presumed release sites; frequencies per release site were therefore about 5 times smaller.) Paired comparisons also indicated a significant increase: of 11 cells that were tested sequentially in the two conditions, 5 had no SCT at all, and the other 6 had a higher SCT frequency in ryanodine than in control $(p<0.02)$. This finding shows that ryanodine is excitatory at $5-10 \mu \mathrm{M}$, as found in other neuronal preparations ${ }^{36}$, and justifies our previous use of a high dose $(100 \mu \mathrm{M})$ in experiments designed to block ryanodine receptors (Figs. 6 and 7, above).

In parallel experiments, the effects of $10 \mu \mathrm{M}$ ryanodine on mIPSCs were examined in 10 cells. Four cells showed a clear $(>$ $30 \%$ ) and significant (Kolmogorov-Smirnov test, $p<0.005$ in each cell) increase in frequency (Fig. 9; mean ratio to control, $1.9 \pm 0.3, n=4$; mean over 10 experiments, $1.37 \pm 0.19)$. These results confirm that low concentrations of ryanodine enhance mIPSC frequency, and show that the proportion of responsive cells is similar to that observed in SCT experiments. Heterogeneity in the functional state of RyRs may explain why some preparations respond poorly to ryanodine. For example, RyRs 
Fig. 9. Low doses of ryanodine increase mIPSC frequency. (a, b) Representative continuous recording of mIPSC $s$ obtained in control condition (a) and 30 to $80 \mathrm{~s}$ after addition of $10 \mu \mathrm{M}$ ryanodine (b). (c, d) Selected sections of the recordings at an expanded time scale; note the high-frequency bursts observed in the presence of ryanodine. The amplitude scale bar in (a) applies to all traces in $(\mathbf{a}, \mathbf{b})$. (e) Distribution of the intervals between consecutive mIPSC $s$ for two min recording in control (black trace) and two min in ryanodine (red trace). The control distribution can be well approximated by a single exponential with time constant of $189 \mathrm{~ms}$, whereas two exponentials are required to describe the distribution obtained in ryanodine (time constants and corresponding initial amplitudes, $40 \mathrm{~ms}, 161 ; 175 \mathrm{~ms}, 12$ ). The fits are superimposed on the traces. (f) mIPSC amplitude histograms obtained in control condition (black bars) and in the presence of ryanodine (white bars). Mean mIPSC amplitudes were $158 \mathrm{pA}$ in control (total number of events, 611) and $140 \mathrm{pA}$ in ryanodine (total number of events, 1644). All histograms represent two min of data.

could be refractory to ryanodine because of a lack of association with accessory proteins such as FKB506-binding protein $^{37}$. The ryanodine-sensitive mIPSCs were organized in bursts, as revealed by a specific enhancement of interevent intervals lower than $50 \mathrm{~ms}$ (Fig. 9e; mean ratio to control, $2.4 \pm 0.6, n=10 ; p<0.05)$. Late events within bursts tended to have lower amplitudes than the first (Fig. 9d), probably because of postsynaptic receptor saturation ${ }^{38}$. This explains why the frequencies of both larger $(>200 \mathrm{pA})$ and smaller $(<200 \mathrm{pA}) \mathrm{mIP}-$ SCs were increased by ryanodine (Fig. 9f). Overall, mIPSC mean amplitudes were not significantly affected by $10 \mu \mathrm{M}$ ryanodine (mean ratio to control, $0.87 \pm 0.03$, for the 4 cells that responded strongly to ryanodine; mean over 10 experiments, $1.01 \pm 0.09$ ).

Axons of basket and stellate cells have $\mathrm{GABA}_{\mathrm{A}}$ receptors ${ }^{39}$ and AMPA-selective ${ }^{40}$ and NMDA-selective ${ }^{41}$ ionotropic glutamate receptors, all of which are potential sources of focal $\mathrm{Ca}^{2+}$ entry. However, SCTs were observed in the presence of a cocktail of blockers $(0.2 \mu \mathrm{M}$ TTX, $10 \mu \mathrm{M}$ NBQX, $50 \mu \mathrm{M}$ APV, $20 \mu \mathrm{M}$ bicuculline; 19 transients in 2 cells), indicating that they were not linked to the activation of $\mathrm{GABA}_{\mathrm{A}}$ receptors or ionotropic glutamate receptors. In addition, somatically recorded current traces during SCTs failed to reveal any deflections indicative of voltage escape in the axon. Taken together, this evidence suggests that SCTs are not due to $\mathrm{Ca}^{2+}$ influx.

The amplitudes and kinetics of SCTs varied widely. Average peak amplitudes were $77 \pm 47 \%$ before and $80 \pm 105 \%$ after addition of ryanodine (mean \pm s.d., 13 cells). Although the two averages are not statistically different, the larger s.d. in ryanodine is attributable to the higher occurrence of very large, apparently multiple events. Many SCTs had fast rise times, limited by the scanning speed (100 ms per frame), and half decay times around $200 \mathrm{~ms}$ (Fig. 8d). However other SCTs were more complex, with slow (Fig. 8c) or multistep rises, longer durations and larger amplitudes; such SCTs were particularly frequent in the presence of ryanodine (data not shown). The slow SCTs in ryanodine may give rise to bursts including multivesicular and monovesicular mIPSCs, in accordance with the complex amplitude distribution of ryanodine-induced events (Fig. 9f). These experiments show that spontaneous $\mathrm{Ca}^{2+}{ }_{\mathrm{i}}$ transients occur at presumed release sites of basket cell axons, and that their frequency is enhanced by $10 \mu \mathrm{M}$ ryanodine.

\section{Discussion}

The hallmark of mIPSCs at the interneuron-Purkinje cell synapse
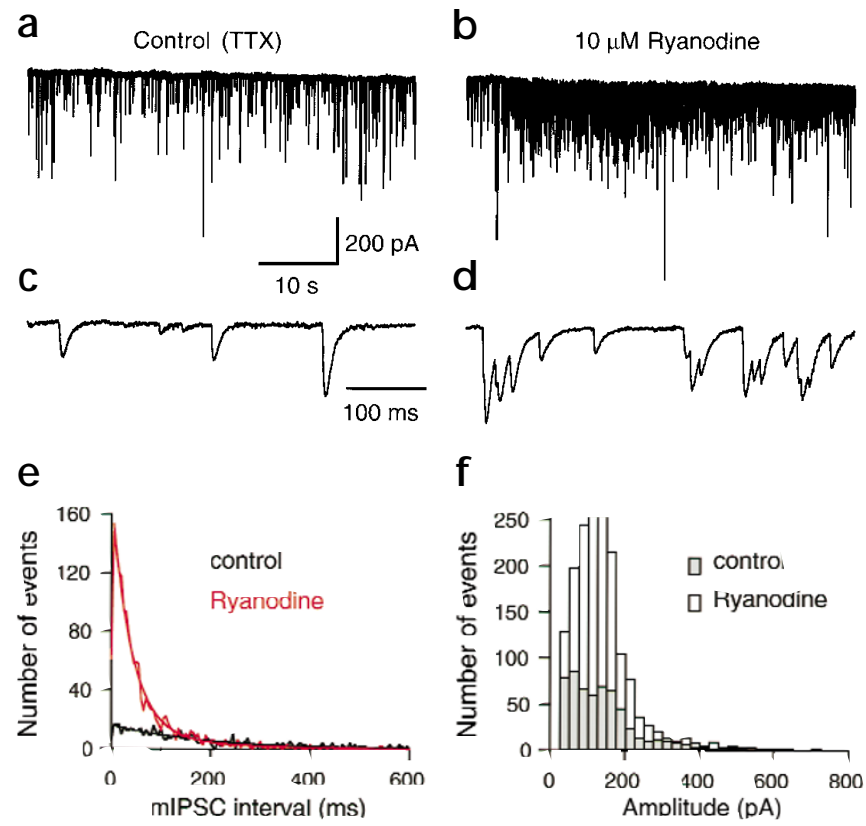

is their highly skewed amplitude distribution, which extends to current sizes in the nA range. Large miniature synaptic events, called giant miniature end-plate potentials (giant mEPPs) have been observed at the neuromuscular junction. However, these differ from lamIPSCs in several important respects: first, their frequency is very low compared to that of normal mEPPs; second, giant mEPPs are insensitive to manipulations of extracellular $\mathrm{Ca}^{2+}$ concentration; third, their rise time is markedly slower than that of ordinary mEPPs. The current interpretation of giant mEPPs is that they result from constitutive exocytosis, possibly of large vesicular structures ${ }^{42}$.

In this study, we have provided three lines of evidence indicating that lamIPSCs are multivesicular and that they are generated by $\mathrm{Ca}^{2+}$ release from ryanodine-sensitive presynaptic stores. The first line of evidence comes from an examination of the amplitude distribution of mIPSCs and of the effects of extracellular $\mathrm{Ca}^{2+}$ concentration on this distribution (Figs. 1-4). Prolonged extracellular $\mathrm{Ca}^{2+}$ removal eliminates lamIPSCs and reduces the mean mIPSC size to $60 \mathrm{pA}$. As discussed above, our evidence indicated that this reflects a presynaptic modification. Because of its slow kinetics, the mIPSC amplitude decrease cannot be due to elimination of TTX-insensitive action potentials. This suggests that extended reduction of presynaptic $\mathrm{Ca}^{2+}{ }_{\mathrm{i}}$ concentration leads to depletion of presynaptic $\mathrm{Ca}^{2+}$ stores, which disrupts multivesicular release.

Second, we present immunocytochemical and pharmacological evidence for the presence of RyRs in presynaptic nerve terminals, which suggests a role for RyRs in regulating GABA release (Figs. 5-7). It will be important to identify the specific receptor subtype involved because our antibody does not distinguish among the three RyR isoforms expressed in the brain. Mostly somatic synapses are stained. This result, combined with the rise time analysis in Fig. 4, suggests that multivesicular release occurs predominantly at somatic synapses. The effects of high ryanodine concentrations on mIPSCs, and particularly the selective elimination of large-amplitude mIPSCs (Fig. 7), indicate that presynaptic RyRs are involved in the generation of lamIPSCs. Finally, our finding that $100 \mu \mathrm{M}$ ryanodine inhibits action-potentialevoked presynaptic $\mathrm{Ca}^{2+}{ }_{\mathrm{i}}$ rises (Fig. 6) indicates that ryanodine- 
sensitive $\mathrm{Ca}^{2+}$ stores are also involved in action potential-evoked release. Trial-to-trial variations of $\mathrm{Ca}^{2+}{ }_{\mathrm{i}}$ transients originating from these stores could underlie the very large, apparently multiquantal variability of IPSC amplitudes observed in paired recordings at basket cell-Purkinje cell connections ${ }^{43}$.

The third line of evidence is the random, local $\mathrm{Ca}^{2+}{ }_{\mathrm{i}}$ transients (SCTs) in basket cell terminals (Fig. 8). Because SCTs are observed in the presence of TTX and blockers of ionotropic GABA and glutamate receptors, and because they are highly localized, they are unlikely to reflect voltage-dependent $\mathrm{Ca}^{2+}$ entry. The effects of ryanodine on SCT frequency indicate that SCTs reflect spontaneous release from ryanodine-sensitive $\mathrm{Ca}^{2+}$ stores. We propose that SCTs underlie multivesicular release. Future work will be needed to establish a parallel between SCTs and the various kinds of $\mathrm{Ca}^{2+}$ release transients described in other preparations, which range from the elementary 'quarks' of muscle fibers ${ }^{33,34}$ to the complex 'puffs' observed in mammalian cells ${ }^{35}$. The short duration of $\mathrm{Ca}^{2+}$ sparks as measured in muscle fibers (with an estimated duration of $\mathrm{Ca}^{2+}$ release of about $5 \mathrm{~ms}$ ) ${ }^{44}$ is compatible with the estimated duration of lamIPSCs synchronization (less than $4 \mathrm{~ms}$ ) derived from our rise time results. Basket cell terminals are elongated structures that contain arrays of release sites spanning several micrometers ${ }^{27}$. $\mathrm{Ca}^{2+}$ sparks occurring in such structures would reach tens of release sites and could therefore provide the synchronization needed to generate lamIPSCs (up to $1.5 \mathrm{nA}$ ) out of individual quantal sizes of $\sim 60 \mathrm{pA}$ each.

Synchronization of miniature synaptic currents, as proposed here, introduces an amplification step in the control of neurotransmitter release, which could be the target of modifications by neuromodulators or by activity-driven synaptic plasticity.

\section{Methods}

Sagittal cerebellar slices from rats aged 10 to 14 days, decapitated after cervical dislocation, were prepared according to described procedures ${ }^{22}$. During recordings, the slices were perfused $(1.5 \mathrm{ml} / \mathrm{min})$ with saline containing $125 \mathrm{mM} \mathrm{NaCl}, 2.5 \mathrm{mM} \mathrm{KCl}, 1.25 \mathrm{mM} \mathrm{NaH}_{2} \mathrm{PO}_{4}, 26 \mathrm{mM}$ $\mathrm{NaHCO}_{3}, 2 \mathrm{mM} \mathrm{CaCl}_{2}, 1 \mathrm{mM} \mathrm{MgCl}_{2}$ and $10 \mathrm{mM}$ glucose, equilibrated with a $95 \% \mathrm{O}_{2}-5 \% \mathrm{CO}_{2}$ mixture ( $\left.\mathrm{pH} 7.3\right)$. All experiments were done at room temperature.

Recordings of mIPSCs from Purkinje cells. For tight-seal whole-cell recording of mIPSCs from Purkinje cells, pipettes $(2.5 \mathrm{M} \Omega)$ were filled with a solution containing $124 \mathrm{mM} \mathrm{CsCl}, 4.6 \mathrm{mM} \mathrm{MgCl}_{2}, 10 \mathrm{mM}$ HEPESCs, $10 \mathrm{mM}$ BAPTA-Cs (Molecular Probes, Eugene, Oregon), $1 \mathrm{mM} \mathrm{CaCl}_{2}$, $0.4 \mathrm{mM} \mathrm{Na}$-GTP and $4 \mathrm{mM} \mathrm{Na}$-ATP ( $\mathrm{pH}$ 7.3). Capacitance cancellation and series resistance $\left(\mathrm{R}_{\mathrm{s}}\right)$ compensation were done as described ${ }^{22}$. Uncompensated $R_{s}$ values did not exceed $10 \mathrm{M} \Omega$. To block ionotropic glutamate receptors, $10 \mu \mathrm{M}$ NBQX and $100 \mu \mathrm{M}$ APV or $2 \mathrm{mM}$ kynurenic acid (Tocris Cookson, Bristol, UK) were included in the extracellular solution. TTX (Sigma-Aldrich, Taufkirchen, Germany) was present throughout the recordings at $200 \mathrm{nM}$. Calcium-free external solutions were prepared by omitting $\mathrm{Ca}^{2+}$ and adding $200 \mu \mathrm{M}$ EGTA- $\mathrm{Na}^{+}$. Membrane potential was held at $-60 \mathrm{mV}$, and currents, filtered at $1.5-2 \mathrm{kHz}$, were sampled continuously at a rate of 200 or $250 \mu$ s per point, with brief interruptions every $3 \mathrm{~min}$ to verify $\mathrm{R}_{\mathrm{s}}$. Detection and analysis of mIPSCs was done offline with routines written in the IGOR-Pro programming environment (Wavemetric, Lake Oswego, Oregon).

In experiments using the $\mathrm{Ca}^{2+}$ channel blocker $\omega$-AGA IVA (Peptide Institute, Osaka, Japan), $0.1 \mathrm{mg} / \mathrm{ml}$ of cytochrome C (Sigma-Aldrich) was included in the external saline before and during drug addition. The toxin was prepared as described in ref. 21. Ryanodine was purchased from Calbiochem (Bad Soden, Germany).

Basket cell $\mathrm{Ca}^{2+}{ }_{\mathrm{i}}$ monitoring. Two-photon laser scanning fluorescence microscopy of basket cells from 11 to 14 days-old rats was done as described $^{29}$ using a homemade two-photon fast scanning system ${ }^{30}$. For studies of action-potential-evoked $\mathrm{Ca}^{2+}{ }_{\mathrm{i}}$ rises, the external solution contained $10 \mu \mathrm{M}$ bicuculline (Tocris Cookson) and recording pipettes ( 4 to $6 \mathrm{M} \Omega$ ) contained $150 \mathrm{mM} \mathrm{KCl}, 4.6 \mathrm{mM} \mathrm{MgCl}, 10 \mathrm{mM}$ HEPES$\mathrm{K}, 0.4 \mathrm{mM} \mathrm{Na}-\mathrm{GTP}, 4 \mathrm{mM} \mathrm{Na}-\mathrm{ATP}(\mathrm{pH} 7.3)$ and $200 \mu \mathrm{M}$ of the $\mathrm{K}^{+}$salt of the $\mathrm{Ca}^{2+}$-sensitive probe Oregon Green-1 (OG1; Molecular Probes). $\mathrm{R}_{\mathrm{s}}$ values in whole-cell recording were 15-35 $\mathrm{M} \Omega$ and were compensated for by $50-70 \%$. Axonal regions $(26 \mu \mathrm{m} \times 10 \mu \mathrm{m})$ were scanned at rates of $67 \mathrm{~ms}$ per scan, with no interval between consecutive scans. A series of 32 scans was started while the cell was held at $-60 \mathrm{mV}$, and a train of four or eight $3 \mathrm{~ms}$ pulses to $0 \mathrm{mV}$ was applied at the end of the eighth scan. After this protocol was repeated 8-12 times at 1-min intervals in control external saline to obtain a reliable baseline, the bath solution was changed to ryanodine-containing saline, and recording continued for 10-20 min. A similar protocol was used to monitor $\mathrm{Ca}^{2+}{ }_{i}$ rises during external $\mathrm{Ca}^{2+}$ removal $\left(0\right.$ added $\mathrm{Ca}^{2+}$ plus $200 \mu \mathrm{M}$ EGTA in the extracellular solution), except that the internal solution contained $1 \mathrm{mM} \mathrm{EGTA}$, and $\mathrm{Cs}^{+}$replaced $\mathrm{K}^{+}$as the main cation; the stimulus was a $50 \mathrm{~ms}$ depolarization to $0 \mathrm{mV}$.

Fluorescence changes were analyzed off-line with laboratory-written software using the IGOR-Pro programming environment (Wavemetric). To study the time course and amplitude of $\mathrm{Ca}^{2+}{ }_{\mathrm{i}}$ rises, the average fluorescence was measured in small 'regions of interest' (ROIs; 25 to 36 pixels, corresponding to 1.56 to $2.25 \mu \mathrm{m}^{2}$ ) and converted to the percentage change in fluorescence: $\Delta \mathrm{F} / \mathrm{F}_{\mathrm{o}}=100 \times\left(\mathrm{F}-\mathrm{F}_{\mathrm{r}}\right) /\left(\mathrm{F}_{\mathrm{r}}-\mathrm{B}\right)$, where $\mathrm{F}$ is the measured fluorescence signal at any given time, $\mathrm{F}_{\mathrm{r}}$ is the average fluorescence from the scans preceding the stimuli, and $B$ is the average value of the background fluorescence from 4 regions in the scanned field that do not contain any part of the dye-filled cell.

Recordings of spontaneous $\mathrm{Ca}^{2+}$ transients were done in cells loaded with a solution containing $140 \mathrm{mM} \mathrm{K}$ gluconate, $9 \mathrm{mM} \mathrm{KCl}, 2.4 \mathrm{mM}$ $\mathrm{MgCl}_{2}, 10 \mathrm{mM}$ HEPES-K, $0.4 \mathrm{mM} \mathrm{Na}-\mathrm{GTP}, 2.4 \mathrm{mM} \mathrm{Na}-\mathrm{ATP}$ (pH 7.3) and $380 \mu \mathrm{M}$ of the $\mathrm{K}^{+}$salt of Fluo-4 (Molecular Probes). An axonal region bearing putative presynaptic terminals was scanned repeatedly with series of 100 scans (scan dimensions, $17 \mu \mathrm{m} \times 24 \mu \mathrm{m}$; $100 \mathrm{~ms}$ per scan; no interval between scans). The scan series was repeated at intervals of 10-20 s. ROI analysis from these scans was done, as explained above, using as $\mathrm{F}_{\mathrm{o}}$ the average of the first 8 scans of each series. To study the spatiotemporal profile of the SCTs, raw images were first converted to $\Delta \mathrm{F} / \mathrm{F}_{\mathrm{o}}$ values (using the average of the first 8 images for $\mathrm{F}_{\mathrm{o}}$ ); 'pseudo line scan' analysis was then done by first drawing a line(s) through neighboring pixels of the axon and then computing the $\Delta \mathrm{F} / \mathrm{F}_{\mathrm{o}}$ pixel values throughout the stack of images, as detailed in ref. 21. The criterion for detection of a SCT was that, in a given ROI, two consecutive time points should have $\Delta \mathrm{F} / \mathrm{F}_{\mathrm{o}}$ values greater than twice the standard deviation of the baseline.

Immunocytochemistry and immunoblot analysis. A rabbit polyclonal antiserum was raised to the carboxy-terminal sequence of 16 amino acids that is $100 \%$ conserved in all known mammalian RyRs (FFPAGDCFRKQYEDQL). A C-terminal cysteine was added to enable conjugation via maleimide activation to keyhole limpet hemocyanin (Pierce Chemical, Rockford, Illinois). New Zealand White rabbits were immunized with the conjugated peptide as described ${ }^{45}$, and specificity was confirmed by ELISA and immunoblot analysis with whole brain, cerebellum and skeletal and cardiac muscle microsomes ${ }^{46}$. For immunoblot analysis, sarcoplasmic and endoplasmic reticulum-enriched microsomes prepared from fast skeletal muscle, cardiac tissue, whole brain and cerebellum ${ }^{47,48}$ were separated on a $5 \%$ SDS polyacrylamide gel ( $30 \mu \mathrm{g}$ protein per lane), the proteins were electrophoretically transferred to PVDF membrane and then probed with either unpurified or affinity-purified antibody at a dilution of 1:1000 (ref. 49). Affinity-purified antibody was prepared by acid elution following incubation of the crude unpurified RyR antisera either with skeletal muscle RyR protein immobilized on PVDF membrane strips or on Protein A-agarose columns (Sigma-Aldrich).

Sagittal cerebellar slices ( $80 \mu \mathrm{m}$ thick) were cut from cerebella prefixed in phosphate-buffered saline (PBS) with $2 \%$ formaldehyde. The slices were incubated in PBS and fixative for $30 \mathrm{~min}$ and permeabilized with Triton-containing PBS for $1 \mathrm{~h}$. After washing, slices were incubated with the RyR antibody for $\sim 20 \mathrm{~h}$. After removal of the remaining antibody by several washes with albumin-containing PBS, the slices were incubated for $3 \mathrm{~h}$ at room temperature with Fluorescein-anti rabbit IgF 
(Vector Laboratories, Burlingame, California); they were then washed and mounted on cover slips. All steps were done at room temperature. Confocal images were taken with an inverted Zeiss LSM 410 laser scan microscope (Jena, Germany), using the argon laser for excitation. Control slices underwent a similar protocol but incubated only with fluorescein-anti rabbit IgF. These slices showed no signal at the settings used to reveal RyR staining.

Unless otherwise specified, statistical values in the text are given as mean \pm s.e.m. Differences between control and test results were examined using Student's paired $t$-test; $p$ values $<0.05$ were considered significant.

\section{ACKNOWLEDGEMENTS}

We thank S. Schmidt for histological work, as well as L. Forti, A. Hernández Cruz and E. Neher for comments on the manuscript. This work was supported by the Deutsche Forschungsgemeinschaft (SFB406) and the European Union (Contract No. ERBFMRX CT98-0236).

\section{RECIVED 25 MAY; ACCEPTED 11 OCTOBER 2000}

1. Katz, B. in The Sherrington Lectures: The Release of Neuronal Transmitter Substances 1-60 (Liverpool Univ. Press, Liverpool, UK, 1969).

2. Redman, S. Quantal analysis of synaptic potentials in neurons of the central nervous system. Physiol. Rev. 70, 165-198 (1990).

3. Bekkers, J. M. Quantal analysis of synaptic transmission in the central nervous system. Curr. Opin. Neurobiol. 4, 360-365 (1994).

4. Bennett, M. R. The origin of Gaussian distributions of synaptic potentials. Prog. Neurobiol. 46, 331-350 (1995).

5. Wall, M. J. \& Usowicz, M. M. Development of the quantal properties of evoked and spontaneous synaptic currents at a brain synapse. Nat. Neurosci. 1, 675-682 (1998).

6. Yoshida, S. Tetrodotoxin-resistant sodium channels. Cell Mol. Neurobiol. 14 227-244 (1994).

7. Nakanishi, S., Maeda, N. \& Mikoshiba, K. Immunohistochemical localization of an inositol 1,4,5-trisphosphate receptor, P400, in neural tissue: studies in developing and adult mouse brain. J. Neurosci. 11, 2075-2086 (1991).

8. Peng, Y.-W., Sharp, A. H., Snyder, S. H. \& Yau, K.-W. Localization of the inositol $1,4,5$-trisphosphate receptor in synaptic terminals in the vertebrate retina. Neuron 6, 525-531 (1991).

9. Narita, K. et al. A Ca ${ }^{2+}$-induced $\mathrm{Ca}^{2+}$ release mechanism involved in asynchronous exocytosis at motor nerve terminals. J. Gen. Physiol. 112, 593-609 (1998).

10. Narita, K. et al. Functional coupling of $\mathrm{Ca}^{2+}$ channels to ryanodine receptors at presynaptic terminals. Amplification of exocytosis and plasticity. J. Gen. Physiol. 115, 519-532 (2000).

11. Mothet, J. P., Fossier, P., Meunier, F.-M., Stinnakre, J., Tauc, L. \& Baux, G. Cyclic ADP-ribose and calcium-induced calcium release regulate neurotransmitter release at a cholinergic synapse of Aplysia. J. Physiol. (Lond.) 507, 405-414 (1998).

12. Peng, Y.-y. Ryanodine-sensitive component of calcium transients evoked by nerve firing at presynaptic nerve terminals. J. Neurosci. 16, 6703-6712 (1996).

13. Smith, A. B. \& Cunnane, T. C. Ryanodine-sensitive calcium stores involved in neurotransmitter release from sympathetic nerve terminals of the guinea-pig. J. Physiol. (Lond.) 497, 657-664 (1996).

14. Krizaj, D., Bao, J.-X., Schmitz, Y., Witkovsky, P. \& Copenhagen, D. R. Caffeinesensitive calcium stores regulate synaptic transmission from retinal rod photoreceptors. J. Neurosci. 19, 7249-7261 (1999).

15. Savic, N. \& Sciancalepore, M. Intracellular calcium stores modulate miniature GABA-mediated synaptic currents in neonatal rat hippocampal neurons. Eur. J. Neurosci. 10, 3379-3386 (1998).

16. Frerking, M., Borges, S. \& Wilson, M. Are some minis multiquantal? J. Neurophysiol. 78, 1293-1304 (1997).

17. Parekh, A. B. \& Penner, R. Store depletion and calcium influx. Physiol. Rev. 77, 901-930 (1997).

18. Stelzer, A., Kay, A. R. \& Wong, K. S. GABA $A_{A}$-receptor function in hippocampal cells is maintained by phosphorylation factors. Science 241, 339-341 (1988).

19. Llano, I., Leresche, N. \& Marty, A. Calcium entry increases the sensitivity of cerebellar Purkinje cells to applied GABA and decreases inhibitory synaptic currents. Neuron 6, 565-574 (1991).

20. Kano, M., Rexhausen, U., Dreessen, J. \& Konnerth, A. Synaptic excitation produces a long-lasting rebound potentiation of inhibitory synaptic signals in cerebellar Purkinje cells. Nature 356, 601-604 (1992).
21. Forti, L., Pouzat, C. \& Llano, I. The spatial distribution of action potentialevoked $\mathrm{Ca}^{2+}$ signals in axons of developing rat cerebellar interneurones. J. Physiol. (Lond.) 527, 31-47 (2000).

22. Llano, I., Marty, A., Armstrong, C. M. \& Konnerth, A. Synaptic- and agonistinduced excitatory currents of Purkinje cells in rat cerebellar slices. J. Physiol. (Lond.) 434, 183-213 (1991)

23. Maconochie, D. J., Zempel, J. M. \& Steinbach, J. H. How quickly can GABA receptors open? Neuron 12, 61-71 (1994).

24. Berridge, M. J., Cheek, T. R., Bennett, D. L. \& Bootman, M. D. in Ryanodine Receptors (ed. V. Sorrentino) 120-153 (CRC, Boca Raton, Florida, 1996).

25. Kuwajima, G., Futatsugi, A., Niinobe, M., Nakanishi, S. \& Mikoshiba, K. Two types of ryanodine receptors in mouse brain: skeletal muscle type exclusively in Purkinje cells and cardiac muscle type in various neurons. Neuron 9, 1133-1142 (1992).

26. Sharp, A. H. et al. Differential immunocytochemical localization of inositol 1,4,5-trisphosphate- and ryanodine-sensitive $\mathrm{Ca}^{2+}$ release channels in rat brain. J. Neurosci. 13, 3051-3063 (1993).

27. Palay, S. L. \& Chan-Palay, V. Cerebellar Cortex: Cytology and Organization (Springer, Berlin 1974).

28. Kondo, S. \& Marty, A. Protein kinase A-mediated enhancement of miniature IPSC frequency by noradrenaline in rat cerebellar stellate cells. J. Physiol. (Lond.) 498, 165-176 (1997).

29. Tan, Y. P. \& Llano, I. Modulation by $\mathrm{K}^{+}$channels of action potential evoked intracellular $\mathrm{Ca}^{2+}$ rises in rat cerebellar basket cell axons. J. Physiol. (Lond.) 520, 65-78 (1999).

30. Tan, Y. P., Llano, I., Hopt, A., Würriehausen, F. \& Neher, E. Fast scanning and efficient photodetection in a simple two-photon microscope. J. Neurosci. Methods 92, 123-135 (1999).

31. Llano, I., Tan, Y. \& Caputo, C. Spatial heterogeneity of intracellular $\mathrm{Ca}^{2+}$ signals in axons of basket cells from rat cerebellar slices. J. Physiol. (Lond.) 502, 509-519 (1997).

32. Cheng, H., Lederer, W. J. \& Cannell, M. B. Calcium sparks: elementary events underlying excitation-contraction coupling in heart muscle. Science 262, 740-744 (1993).

33. Niggli, E. Localized intracellular calcium signalling in muscle: Calcium sparks and calcium quarks. Annu. Rev. Physiol. 61, 311-335 (1999).

34. Ríos, E. \& Stern, M. D. Calcium in close quarters: Microdomain feedback in excitation-contraction coupling and other cell biological phenomena. Annu. Rev. Biophys. Biomol. Struct. 26, 47-82 (1997).

35. Koizumi, S. et al. Characterization of elementary $\mathrm{Ca}^{2+}$ release signals in NGFdifferentiated PC12 cells and hippocampal neurons. Neuron 22, 125-137 (1999).

36. Llano, I., DiPolo, R. \& Marty, A. Calcium induced calcium release in cerebellar Purkinje cells. Neuron 12, 663-673 (1994).

37. Brillantes, A. B. et al. Stabilization of calcium release channel (ryanodine receptor) function by FK506-binding protein. Cell 77, 513-523 (1994).

38. Auger, C. \& Marty, A. Heterogeneity of functional synaptic parameters among single release sites. Neuron 19, 139-150 (1997).

39. Pouzat, C. \& Marty, A. Somatic recording of GABAergic autoreceptor current in cerebellar stellate and basket cells. J. Neurosci. 19, 1675-1690 (1999).

40. Bureau I. \& Mulle C. Potentiation of GABAergic synaptic transmission by AMPA receptors in mouse cerebellar stellate cells: changes during development. J. Physiol. (Lond.) 509, 817-831 (1998).

41. Glitsch, M. \& Marty, A. NMDA increases the rate of miniature IPSCs in cerebellar Purkinje cells and interneurons. J. Neurosci. 19, 511-519 (1999).

42. Sellin, L. C., Molgó, J., Törnquist, K. \& Hansson, B. On the possible origin of "giant or slow-rising" miniature end-plate potentials at the neuromuscular junction. Pflügers Arch. 431, 325-334 (1996).

43. Vincent, P. \& Marty, A. Fluctuations of inhibitory postsynaptic currents in Purkinje cells from rat cerebellar slices. J. Physiol. (Lond.) 494, 183-199 (1996).

44. Lacampagne, A., Ward, C. W., Klein, M. G. \& Schneider, M. F. Time course of individual $\mathrm{Ca}^{2+}$ sparks in frog skeletal muscle recorded at high time resolution. J. Gen. Physiol. 113, 187-198 (1999).

45. Tunwell, R. E. A. et al. The human cardiac ryanodine receptor-calcium release channel; identification, primary structure and topological analysis. Biochem. J. 318, 477-487 (1996).

46. Mackrill, J. J., Challiss, R. A. J., O’Connell, D. A., Lai, F. A. \& Nahorski, S. R. Differential expression and regulation of ryanodine receptor and inositol 1,4,5trisphosphate receptor $\mathrm{Ca}^{2+}$ release channels in mammalian tissues and celllines. Biochem. J. 327, 251-258 (1997).

47. Lai, F. A., Erickson, H., Rousseau, E., Liu, Q. Y. \& Meissner, G. Purification and reconstitution of the calcium release channel from skeletal muscle. Nature 331, 315-319 (1988).

48. Anderson, K. et al. Structural and functional characterization of the purified cardiac ryanodine receptor- $\mathrm{Ca}^{2+}$ release channel complex. J. Biol. Chem. 264, 1329-1335 (1989).

49. Meissner, G., Rousseau, E. \& Lai, F. A. Structural and functional correlation of the trypsin-digested $\mathrm{Ca}^{2+}$ release channel of skeletal muscle sarcoplasmic reticulum. J. Biol. Chem. 264, 1715-1722 (1989). 